
Jones, the orthopaedic and cosmetic surgeon who founded Celltex, argued that the federal government was overstepping its bounds. The company's therapies, he said, are not biological drugs, but tissue transplants, which typically do not require clinical trials to prove that they work. The drama raised and dashed the hopes of patients, many of whom rallied to support Celltex. Now, some in the industry worry that the turmoil will tar the entire field. "It doesn't serve the interests of patients or the medical community at large," says Gil Van Bokkelen, head of Athersys, a biotech firm in Cleveland, Ohio, that has been cooperating with the FDA to test stem-cell treatments in clinical trials.

Celltex has declined to comment on its business decisions, but it has been promising its patients a reboot, saying that it will publish the results of preliminary studies; start the FDA drug approval process so that it can resume treatments in the United States; and make its stem-cell treatments available in Mexico (see Nature http://doi.org/kdd; 2013). Although many former patients continue to support the company's endeavours, some, such as McFarlane, see the firm as an unfortunate distraction. "Any bad stem-cell PR is detrimental to the overall picture, which is positive," she says.

\section{HOME-GROWN THERAPY}

In an earnest Southern drawl, Jones recounted how he co-founded Celltex. He was one of the headline speakers at the first Houston Stem Cell Summit at the Houstonian Hotel, a plush resort surrounded by 7 hectares of woods. Jones said that he experienced the miracle of stem cells first-hand in 2010 when he travelled to Japan to receive infusions to treat his crippling arthritis. His cells came from RNL Bio, a stem-cell company based in Seoul. Within three months, he said, he could do pilates and work as hard as he had in his youth.

But it irked Jones that he and others had to board a plane to get better. So, with the help of David Eller, a former executive of DuPont in Europe and a friend of governor Perry, he gathered the $\$ 30$ million he needed to gain exclusive rights from RNL to use its stem-cell processing and banking technology in the United States.

With no background in stem cells, "I had to start from scratch", Jones recalled. "I knew that I was the only game in town. So I learned to do liposuction, and I started doing liposuction on anybody that wanted stem cells." Perry, a charismatic politician and one-time presidential hopeful, became Jones' first patient in July 2011, seeking treatment for his recurring back pain. Jones said that he tried to maintain a low profile for the company - not even establishing a website for months, relying instead on personal recommendations - but attention soon followed.

Operating in a state that has historically bristled under big government, Celltex appealed not only to desperate patients but also to the ideals of the political and religious right and their opposition to big government and embryonic stem-cell research. It campaigned for its cause at intimate 'educational forums' at the Houstonian, arguing that it could already provide ethically acceptable treatments with adult stem cells. Patients spread the word at churches, and bloggers praised the company for asserting patients' rights. When prospective clients showed up in his office, Jones would tell them of his experience; at times, he reportedly wept. By October 2012, 233 people had been treated with Celltex stem cells.

Celltex offered treatments with 'mesenchymal stem cells' (MSCs), which are found in bone marrow, muscle, fat and other tissue. In the procedure licensed from RNL, the cells are extracted from just five grams or so of fatty tissue, then cultured, expanded and banked. Doctors could then administer the cultured stem-cell concoction intravenously.

RNL developed its method for isolating and culturing MSCs in 2006, and within four years, 7,000 patients had received its cells - for disorders including stroke, renal failure, asthma, psoriasis and MS. The recoveries - recounted in anecdotes on its website and in the book The Grace of Stem Cells by RNL chairman JeongChan Ra (Tate Publishing, 2012) — are often complete and miraculous. Some patients have the treatment for fatigue, to remove wrinkles or for "restoring the skin's elasticity", Ra writes in his book. But even in South Korea, which seems to have approved more adult-stem-cell treatments than any other country, none of RNL's treatments has been approved. That is why Jones and others had to travel to Japan or China to receive them.

MSCs do have therapeutic potential. Research over the past ten years has suggested that they home in on damaged or inflamed tissues and have various roles in repair, releasing molecules that suppress an overactive immune system, stabilize newly forming blood vessels or prevent cells from dying ${ }^{1}$. Initial fears that they might take hold and become cancerous subsided with evidence that they disappear after a short time in the body ${ }^{2}$. There have been reports of complications, such as "catastrophic demyelinating encephalomyelitis", a life-threatening inflammation of the brain ${ }^{3}$. But there is a growing consensus that MSCs are safe ${ }^{4}$.

Arnold Caplan from Case Western Reserve University in Cleveland, Ohio, did pioneering work on MSCs and refers to their action as "hit and run" healing. More than 250 MSC trials are ongoing or completed, he told the audience at the October summit. And even though most of these studies are small and none has led to regulatory approval for widespread use in the United States or Europe, Caplan says that he would use the cells. "If I had MS, I would be getting this therapy. I'd probably go offshore." That is not a view endorsed by the International Society for Stem Cell Research in Skokie, Illinois, however, which urges prospective patients to be cautious about stem-cell tourism.

Safety also depends on how cells are handled,
TEXAS THROWDOWN

2006 Seoul-based RNL Bio devises stem-cell extraction and cultivation methods. Delivery of cells to patients, prohibited in South Korea, is done in Japan and China.

May 2010 Orthopaedic surgeon Stanley Jones travels to Japan for stem cells to treat his arthritis.

March 2011 Jones and executive David Eller ink US\$30-million deal to license RNL Bio's methods in the United States and create Celltex in Texas.

July 2011 Texas governor Rick Perry (pictured), who had backed legislation to support stem-cell treatments in Texas, becomes Celltex's first patient.

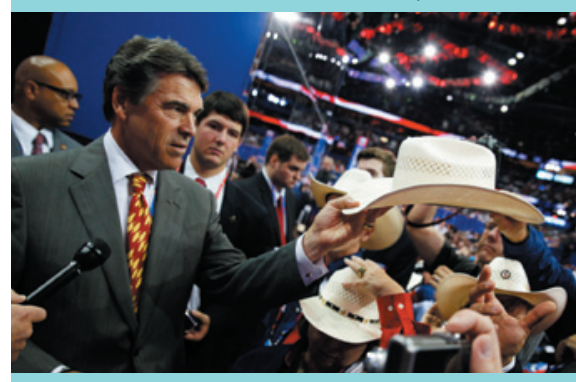

February 2012 Bioethicist Glenn McGee resigns as adviser to Celltex amid controversy.

April 2012 The US Food and Drug Administration (FDA) finds problems at Celltex's cell-processing plant. The Texas Medical Board sets rules allowing Celltex to bypass the FDA.

July 2012 Six California patients who received stem-cell treatments from RNL Bio sue the company for misrepresenting the benefits.

September 2012 The FDA warns Celltex that its treatments require federal approval before use in patients.

October 2012 Celltex tells patients that it must suspend stem-cell treatments.

November 2012 Celltex and RNL Bio sue each other over payments for storing and maintaining cells.

January 2013 Celltex announces that it will restart its treatments, in Mexico, and will meet with the FDA in March. 
and the FDA has voiced concerns about Celltex's operations. In April 2012, an FDA inspection found a laundry list of problems - 79 in all - at the Sugar Land plant that the firm ran with RNL. The list included failure to confirm that equipment was sterile, and operating table-top centrifuges and incubators on the floor. Labels on one bottle said different things in Korean and English and one product used in the culture media was marked "not intended for human or animal diagnostic or therapeutic uses".

Celltex blamed a "language barrier". In a formal statement, it said it was maintaining an "open line of communication" and a "cooperative relationship" with the FDA and that it would address the problems. "Celltex and its partner RNL Bio process stem cells in a safe, sterile laboratory with procedures that ensure cell viability and integrity," the company said.

But the FDA also found fault with the therapy itself - in particular, it challenged Jones's claim that the procedure qualifies as a treatment with a patient's own cells and therefore falls outside FDA jurisdiction. To qualify as such, the cells would have to be "minimally manipulated" and be implanted for "homologous use", meaning that they carry out the same functions in the treated tissue as they do in the tissue from which they are extracted.

On 24 September, the FDA sent a warning letter to Celltex saying that because the firm's processing "alters the original relevant characteristics" of the fat tissue, the cells are not considered minimally manipulated. And because the fat-derived MSCs were used to treat problems in other tissue, such as nerve tissue in MS, it does not count as homologous use. The FDA demanded that Celltex comply and show that it had fixed all the manufacturing problems and that it had approval to use the stem cells, or face regulatory action, which could include seizure of the facility or an injunction.

Celltex responded to the FDA on 16 October, again arguing that the preparation "does not alter the relevant biological characteristics of the MSCs". It also claimed that MSCs are known to spur the growth of blood vessels, regulate the immune response and dampen inflammation, and that those are presumably the roles the cells carry out in both the transplant and the original fat tissue.

Peter Connick of the University of Cambridge, UK, who is running clinical studies with MSCs, says that he suspects that the FDA is correct that MSCs function differently in different tissue. "The ability of MSCs to instruct neural stem-cell fate decisions, for example, is by definition not something that they could do in their bone-marrow niche," he says.

On 25 October, Celltex notified its customers that it had to halt treatments while it prepared to start an FDA-approved clinical trial. The message was apologetic, but cast the blame on the FDA. "I know that many of you are deeply hurting due to the FDA's decision to regulate your own stem cells as a drug," it read.
That sentiment was reflected at the October summit, which occurred ten days later. Sponsored by Celltex, the conference had attracted representatives from many of the country's most promising stem-cell companies and banks - including those that have been working through the FDA approval process. Perry spoke, praising the "wildcat spirit" in Texas and bemoaning the FDA's "crippling bureaucratic infrastructure". Lawyers and ethicists debated the need for regulations on stem cells along-

\section{"Any bad stem-cell PR is detrimental to the overall picture."}

side patients, some of whom were wheelchairbound. "The FDA is trying to screw you," one participant told Eller during a coffee break.

Yet many in the industry back the FDA's position. Van Bokkelen of Athersys was the previous head of the Alliance for Regenerative Medicine in Washington DC, which represents the interests of 100 or so US companies, many of which, like Athersys, have stem-cell treatments undergoing FDA-approved clinical trials. He says that stem-cell treatments may require changes in existing regulations, but that he hopes to work these out collaboratively with the FDA. "Rather than coming at them with pitchforks, I wanted to engage in dialogue to come up with ways to explore areas of uncertainty," he says.

\section{FRUSTRATED PATIENTS}

Mary Pat Moyer, the founder of INCELL, a lifescience services company based in San Antonio, Texas, started her presentation at the October summit with a slide that criticized the "stem-cell cowboy" mentality that Celltex has espoused. Frustrated Celltex customers had contacted her about storing their cells in her repository (she refused), and she says that she was surprised to hear how little data the company had collected on patients from ongoing tests. "It's frustrating. If they have so many patients, they should provide some guidance" in terms of what dosing works best for each disease.

Despite being part of a study, McFarlane notes that Celltex didn't ask her about her progress on her treatment until January this year. She had hounded the company for more information about her treatments. Celltex showed, she says, a "total lack of follow-up or investigation".

Many researchers are pursuing more rigorous trials. For example, Connick is leading a clinical trial of stem cells to treat MS in which he is using various neurological tests as well as techniques to show improvement in the neurons. Connick says that MSC therapy seems to be "feasible, safe and may slow the neuroaxonal loss" that leads to the progressive disability in $\mathrm{MS}^{5}$. He does concede, however, that "questions remain about the long-term safety and long-term efficacy", and that he would not advise patients to try the treatment outside of clinical trials.

In November 2012, Celltex's troubles deepened. RNL Bio and Celltex sued each other over how much money Celltex needed to pay for the services that RNL was providing at the Sugar Land plant. Celltex had to file a restraining order to get access to the cells.

But in the months since the company halted treatments, Celltex has said that it is making overtures to the FDA, and that it will now collect information from its clinical studies. In January, it told patients that a clinical research organization was evaluating data and that patients should expect a follow-up call about their conditions. It also told its patients that it would start approved clinical trials "shortly after" a meeting with the FDA in March. And it announced that it would be providing treatments through physicians in Mexico.

Most patients, meanwhile, are frustrated by the delays. Debbie Bertrand, who has MS, said that, before going to Celltex, she was turned away from five approved clinical trials because her symptoms weren't severe enough to qualify. "I don't want to wait till I'm bad enough," she says. And many are mistrustful of the FDA, suspecting that it is in cahoots with big drug companies to peddle ineffective treatments. "I have tried all of the FDA-approved MS drugs, which had horrible life-threatening side effects," says Sammy Jo Wilkinson, an MS patient and Celltex client who gave a moving account of her ordeal at the October summit.

Other companies now seem poised to fill the void left by Celltex, albeit less brazenly. According to Turner, who has followed closely the proliferation of companies providing such treatments in the United States, "businesses are becoming more cautious about the language they use on their websites. Many of them now emphasize that they engage in no more than minimal manipulation of stem cells before administering them." He adds, "In my opinion, the reason the FDA's letter to Celltex does not seem to have had a major deterrent effect on other companies is that marketing and administering autologous stem cells is so profitable."

McFarlane, for one, still hopes to find a stem-cell therapy that works for her. "Even though I'm disenchanted with Celltex, I still hold out great hope for adult stem-cell treatment in general. I personally have not been helped ... but I have seen some amazing results for others." - SEE EDITORIAL P.147

David Cyranoski writes for Nature from Tokyo.

1. Caplan, A. I. \& Correa, D. Cell Stem Cell 9, 11-15 (2011).

2. von Bahr, L. et al. Stem Cells 30, 1575-1578 (2012).

3. Alderazi, Y. J. et al. J. Child Neurol. 27, 632-635 (2012).

4. Lalu, M. M. et al. PLoS ONE 7, e47559 (2012).

5. Connick, P. et al. Lancet Neurol. 11, 150-156 (2012). 